ści, nieumyślności bądź braku winy uczestnika rynku. Wydaje się zatem, że obecna definicja manipulacji instrumentem finansowym, w zakresie jakim stanowi podstawę do ustalania znamion przestępstw z art. 183 Ustawy powinna niezwłocznie ulec zmianie.

Maria Stożek, prawnik, doktorantka UJ

\title{
GLOSA \\ DO UCHWALY IZBY KARNEJ SĄDU NAJWYŻSZEGO Z DNIA 27 LUTEGO 2007 R., I KZP 36/0689
}

„Pojęcie środka odurzającego w rozumieniu art. 178a k.k. obejmuje nie tylko środki odurzające wskazane w ustawie z dnia 29 lipca 2005 r. o przeciwdziałaniu narkomanii (Dz. U. Nr 179, poz. 1485), lecz również inne substancje pochodzenia naturalnego lub syntetycznego, działające na ośrodkowy układ nerwowy, których użycie powoduje obniżenie sprawności w zakresie kierowania pojazdem."

Glosowane orzeczenie jest przedmiotem licznych sporów w doktrynie. Problem zarysował się już na gruncie kodeksu karnego z 1969 r., a rozwiązanie tego sporu ma niebagatelny wpływ na orzecznictwo w sprawach o prowadzenie pojazdu pod wpływem środka odurzającego. Wyprzedzając ocenę słuszności argumentów Sądu Najwyższego, przytoczonych na poparcie glosowanej uchwały, należy zaznaczyć, że jednoznacznej odpowiedzi na pytanie, czym jest środek odurzający i jakie substancje zalicza się do tych środków, udziela przepis art. 4 pkt 26 ustawy z dnia 29 lipca 2005 r. o przeciwdziałaniu narkomanii i na gruncie tej ustawy nie można pojęć „środka odurzającego” i „substancji psychotropowej" stosować zamiennie. Zgodnie z tym przepisem „środek odurzający" to każda substancja pochodzenia naturalnego lub syntetycznego działająca na ośrodkowy układ nerwowy, określona w wykazie środków odurzających stanowiącym załącznik do ustawy. Ustawa ponadto w analogiczny sposób definiuje „substancję psychotropową”. Podobnie jak w przypadku środka odurzającego, wykaz substancji psychotropowych został zamieszczony w załączniku do ustawy. Omawiany akt prawny wyróżnia również „,środek zastępczy”, czyli substancję w każdym stanie fizycznym, która jest trucizną lub środkiem szkodliwym, używaną zamiast lub w takich samych celach innych, niż medyczne, jak środek odurzający lub substancja psychotropowa. Nie ma wykazu środków zastępczych, co oczywiste, biorąc pod uwagę ilość substancji, które odpowiadają takiej charakterystyce. 0 ile ustawa o przeciwdziałaniu narkomanii jednoznacznie określa zakres pojęcia „środek odurzający” i „substancja psychotropowa”, to w kodeksie karnym takie definicje nie zostały sformułowane, mimo że pojęcie „środka odurzającego" pojawia się w kilku jego przepisach, zamieszczonych w artykułach: 42 $\S 2$ i 3, 47a, 93, 96, 178, 178a $\S \S 1$ i 2, 179 oraz 180. Nadmienić należy przy tym, iż istnieje tu pewna niekonsekwencja terminologiczna która, zdaniem Sądu Najwyższego wyrażonym w glosowanej uchwale, jest również argumentem przemawiającym za szerokim rozumieniem pojęcia „środek odurzający”.

\footnotetext{
${ }^{89}$ OSNKW 2007, nr 3, poz. 1.
} 
Pojęcie substancji odurzającej i psychotropowej jest wyraźnie rozdzielane na gruncie prawa międzynarodowego (zob. Jednolita Konwencja o środkach odurzających z 1961 r. ${ }^{90}$ i Konwencja o środkach psychotropowych z 1961 r. ${ }^{91}$ ). Właśnie ze względu na obowiązywanie w Polsce tego prawa, do krajowego porządku prawnego, tj. do ustawy z dnia 29 lipca 2005 r. o przeciwdziałaniu narkomanii, wprowadzono podział na środki odurzające, substancje psychotropowe i środki zastępcze. Zmian tych nie uwzględniono jednak w pozostałych aktach prawnych, w tym w przepisie art. 178a k.k. Zapatrywanie Sądu Najwyższego, choć uzasadnione względami racjonalności i celowości (interpretacja usuwająca lukę prawną w zakresie penalizacji, jaka istnieje na gruncie przepisu art. 178a k.k.), może być kwestionowana przede wszystkim z dwóch, poniżej omówionych, powodów.

Po pierwsze, za przyjęciem interpretacji „środka odurzającego” w rozumieniu nadanym temu pojęciu regulacją ustawy o przeciwdziałaniu narkomanii przemawia założenie spójności systemu prawnego. Zgodnie z tym założeniem, jeżeli ustawodawca zdefiniował jakieś pojęcie, zamieszczając jego znaczenie normatywne $\mathrm{w}$ definicji legalnej, powinno ono mieć jednolite znaczenie w całym systemie prawnym, chyba że ustawodawca postanowił inaczej (zgodnie z zakazem interpretacji homonimicznej. Rozmaite rozumienie pojęcia „środka odurzającego”, w zależności od specyfiki regulacji, w której się ono pojawia, prowadzi do niespójności terminologicznej w obowiązującym prawie. W konsekwencji pojęcie „środka odurzającego” byłoby przyjmowane ad hoc, w zależności od aktu prawnego, którego przepisy zostałyby naruszone.

Przyjęcie interpretacji zaprezentowanej przez Sąd Najwyższy potencjalnie mogłoby prowadzić do objęcia penalizacją wszystkich substancji, które oddziałują na ośrodkowy układ nerwowy. Należy podać w wątpliwość dopuszczalność i zasadność rozszerzania zakresu pojęcia „środka odurzającego" na tak wiele substancji, i to bez jednoczesnego ścisłego (a nie ocennego) doprecyzowania, o jakie substancje chodzi. Istnieje również obawa, czy taki zabieg interpretacyjny nie wprowadzi niepewności odnośnie katalogu czynów karalnych. Celowość takiego rozwiązania jest przy tym wątpliwa z praktycznego punktu widzenia, a to ze względu na niepewność co do technicznych możliwości stwierdzenia stopnia wpływu poszczególnych substancji na zdolność do kierowania pojazdem mechanicznym. Warto wspomnieć, że nawet legalne substancje (np. lekarstwa na kaszel, czy grypę) mogą negatywnie oddziaływać na ośrodkowy układ nerwowy. Ponadto, stosując tylko językową (szeroką) wykładnię pojęcia „środka odurzającego" konsekwentnie należałoby uznać, że również alkohol winien być za taki traktowany, co oznaczałoby bezcelowość rozróżnienia przez ustawodawcę w przepisie art. 178a k.k. „stanu pod wpływem środka odurzającego” od „stanu nietrzeźwości”.

Drugą, bardziej istotną, negatywną konsekwencją przyjęcia poszerzonej definicji środka odurzającego, jest - jak się wydaje - naruszenie zakazu wykładni rozszerzającej na niekorzyść oskarżonego ${ }^{92}$, a tym samym naruszenie przepisu art. 42 ust. 1 Konstytucji RP i art. 1 k.k. ${ }^{93}$ Obowiązek przestrzegania zasady nullum crimen, nulla poena sine lege wynika również $\mathrm{z}$ obowiązującego $\mathrm{w}$ Polsce prawa międzynarodowego ${ }^{94}$. Sąd Naj-

\footnotetext{
${ }^{90}$ Dz.U. z 1996 Nr 45, poz. 277.

${ }^{91}$ Dz.U. z 1976 Nr 31, poz. 180.

${ }^{92}$ Por. K. Krajewski, jw., s. 33.

${ }^{93} \mathrm{~W}$ których to przepisach wyrażone zostały naczelne zasady prawa karnego - zasada nullum crimen, nulla poena sine lege, a dokładniej- zasada nullum crimen sine lege stricta (zasada określoności czynu zabronionego pod groźbą kary).

${ }^{94}$ Zasada nullum crimen, nulla poena sine lege została na przykład wyrażona w art. 15 ust. 1 Międzynarodowego Paktu Praw Obywatelskich i Politycznych (Dz.U. z 1977 Nr 38, poz. 167, załącznik).
} 
wyższy w orzeczeniu z 4 kwietnia 2000 r. ${ }^{95}$ wskazał, iż zgodnie z zasadą nullum crimen sine lege stricta podstawą odpowiedzialności karnej może być tylko zgodność czynu ze znamionami typu czynu zabronionego. Należy uznać, że z zasady tej wynikają reguły dopuszczalnych metod wykładni prawa karnego ${ }^{96}$. Dokonując takiej wykładni znamienia „,środka odurzającego”, jak w niniejszej uchwale (i rozszerzając tym samym zakres penalizacji), można mieć wątpliwości, czy Sąd Najwyższy nie przekroczył granic wykładni, i czy rozwiązując w ten sposób problem ewentualnej luki prawnej istniejącej w regulacji przepisu art. 178a k.k. ${ }^{97}$, nie wkroczył w kompetencje zarezerwowane dla ustawodawcy. Podstawowym zadaniem prawa karnego jest ochrona społeczeństwa. Prawo karne powinno chronić jednak nie tylko członków społeczeństwa przed sobą nawzajem, ale również chronić obywateli przed nadmierną ingerencją organów władzy państwowej w ich prawa i wolności pod pretekstem wykonywania funkcji ochronnej. W ten sposób prawo to, obok funkcji ochronnej, wypełnia również funkcję gwarancyjną.

Reasumując powyższe rozważania, należy stwierdzić, że słuszne jest rozumowanie Sądu Najwyższego, iż artykuł 178a k.k. powinien swoim zakresem obejmować również substancje psychotropowe i inne substancje, negatywnie oddziałujące na ośrodkowy układ nerwowy, których użycie powoduje obniżenie sprawności w zakresie kierowania pojazdem. Chociaż jest to rozwiązanie racjonalne i pożądane, takie rozumienie pojęcia „środka odurzającego” opiera się jednak w istocie na wykładni rozszerzającej znamienia typu czynu zabronionego (wykładnia na niekorzyść oskarżonego), niedopuszczalnej na gruncie prawa karnego. Co więcej, wykładnia systemowa wymaga przyjęcia jednolitego znaczenia tego pojęcia na gruncie całego systemu prawnego. Z praktycznego punktu widzenia nie jest również możliwe objęcie pojęciem „środka odurzającego" wielu, bliżej nieokreślonych substancji chemicznych, ze względu na brak możliwości zbadania ich zawartości w organizmie.

Wobec powyższego, oraz z uwagi na ratio legis przepisu art. 178 a k.k., pożądanym byłoby sankcjonowanie na gruncie przepisu art. 178a k.k. prowadzenia pojazdu mechanicznego nie tylko w stanie wywołanym przez środki odurzające w rozumieniu ustawy z dnia 29 lipca 2005 r. o przeciwdziałaniu narkomanii, ale również w stanie podobnym do stanu odurzenia wywołanym przez inne substancje. Aby penalizować prowadzenie pojazdu mechanicznego pod wpływem wszystkich środków działających na ośrodkowy układ nerwowy, należałoby zmienić treść przepisu. Nie byłaby uzasadniona recepcja pojęcia „substancja psychoaktywna”98 do art. 178a k.k. Pojęcie to obejmuje swoim zakresem zarówno substancje odurzające, psychotropowe, ale również substancje, które są w powszechnym użyciu (kofeina, nikotyna). Nie jest więc zgodne z ratio legis przepisu sankcjonowanie zachowań polegających na prowadzeniu pojazdu pod wpływem substancji psychoaktywnej. Uzasadnionym wydaje się natomiast penalizowanie zachowania polegającego na prowadzeniu pojazdu „(..) w stanie nietrzeźwości, albo pod wpływem środka odurzającego, substancji psychotropowej lub innego podobnie działającego środka". ${ }^{99}$ Byłoby wówczas wiadomo, że ustawodawca nie odwołuje się tylko do środków odurzających, ale również do środków psychotropowych oraz sub-

\footnotetext{
${ }^{95}$ II KKN 335/99 (LEX nr 50896).

${ }^{96}$ A. Zoll [w:] A. Zoll (red.): Kodeks karny. Część ogólna. Komentarz, t. 1, Kraków 2007, s. 45-49.

${ }^{97} \mathrm{Nie}$ ulega bowiem wątpliwości, że z punktu widzenia ochrony dobra, jakim jest zdrowie publiczne i bezpieczeństwo w komunikacji (dobra prawne chronione odpowiednio przez ustawę o przeciwdziałaniu narkomanii i przez kodeks karny) nie tylko środki odurzające ujęte w załączniku do wspomnianej ustawy winny podlegać sankcjonowaniu na gruncie przepisu art. 178a k.k.

${ }^{98}$ K. Łucarz, A. Muszyńska: Pojęcie środka odurzajqcego w prawie karnym, „Państwo i Prawo” 2008, z. 6, s. 102.

${ }^{99}$ Por. K. Krajewski, jw., s. 41.
} 
stancji działających podobnie czyli tych substancji psychoaktywnych, które wywołują taki stan, podobny do stanu nietrzeźwości lub odurzenia, który stanowi zagrożenie dla ruchu drogowego.

Katarzyna Kita, apl adw.(Kielce)

\section{NIEPEŁNOSPRAWNOŚĆ, INWALIDZTWO, NIEZDOLNOŚĆ DO PRACY - ROZRÓŻNIENIE DEFINICJI}

W powszechnym użyciu stosowane są trzy terminy: inwalida, niezdolny do pracy i niepełnosprawny. Przeciętny człowiek nie widzi między nimi różnicy i stosuje je zamiennie. Dopiero, gdy sam będzie chciał „skorzystać” z którejś z tych instytucji, a zatem stanie się niezdolny do pracy, czy niepełnosprawny, wielość pojęć, procedur, instytucji, biurokracja, spowodują w pierwszej chwili niezrozumienie, przy braku uproszczonego poinformowania przez stosowne organa. Nierzadko osoby, posiadające status niezdolnej do pracy (inwalidy) czy niepełnosprawnej po przejściu wszystkich procedur nie do końca rozróżniają jakie przywileje z czego wynikają. Stąd też w doktrynie tego przedmiotu pojawiła się krytyka zmiany terminologii. ${ }^{100}$

Niezdolność, według słownika Języka Polskiego, jest to pewnego rodzaju brak predyspozycji do łatwego opanowania pewnych umiejętności, niemożliwość podołania czemuś, czy dokonania czegoś. ${ }^{101}$ Zdefiniowanie terminu „praca”, pomimo swojej wieloznaczności nie stwarza dylematu, gdyż rozstrzygnięcie znaczenia zależy od kontekstu w jakim jest użyte w danym momencie. Niezdolność do pracy jest to brak predyspozycji do wykonywania pracy zarobkowej, tj. zdobywania środków do zaspokajania potrzeb swoich i najbliższych osób. Ten omawiany jest związany ze stanem zdrowia, który ma bezpośredni wpływ na możliwości świadczenia pracy. Może on być przejściowy, jaki jest niezbędny do powrotu do zdrowia, określany jako czasowa niezdolność do pracy lub wymagający dłuższej rekonwalescencji, nie zawsze prowadzącej do pełnego powrotu do zdrowia i możliwości wykonywania uprzedniej pracy, określany w niniejszym artykule jako rentowa niezdolność do pracy.

Nie bez powodu $\mathrm{w}$ związku $\mathrm{z}$ ostatnim terminem kojarzona jest powstała znacznie wcześniej używana nazwa „inwalidztwo”. Określenie to wywodzi się od łacińskiego słowa „invalidus” stosowanego do określenia człowieka słabego, bezsilnego, chorego, które to słowo z kolei wywodzi się od „validus” tłumaczonego z języka łacińskiego jako mocny, zdrowy. Inwalidą zgodnie ze Słownikiem Wyrazów Obcych, jest osoba pozbawiona całkowicie albo częściowo zdolności do pracy z powodu kalectwa albo utraty zdrowia. ${ }^{102}$

Inwalida, osoba niezdolna do pracy, niepełnosprawny są zamiennie stosowane i powszechnie używane. Tylko one mogą zostać uznane za terminy prawnicze, a to ze względu na ich definicje legalne. Wątpliwość, co do zasługiwania na miano terminu prawniczego, może ewentualnie powstać w przypadku inwalidztwa, ale uwzględniając fakt, iż istniała jego definicja legalna zawarta w uchylonym obecnie ustawodawstwie, nie powinna w ogóle mieć miejsca.

\footnotetext{
${ }^{100}$ Por. U. Jackowiak Niezdolność do pracy zastapi inwalidztwo, PUSiG, 1997 Nr 7, s.14;

101 Słownik Języka Polskiego, PWN, Warszawa,

${ }^{102}$ W. Kopaliński, Słownik wyrazów obcych i zwrotów obcojęzycznych, Wiedza Powszechna, Warszawa, 1989;
} 